\title{
Characteristics of HOTS Oriented Learning at the Elementary School Level
}

\section{Isti Aulia Maspupah}

SD Negeri Sindangjaya 03

istiaulia92@gmail.com

\section{Article History}

received $3 / 12 / 2020$

\begin{abstract}
Teachers are always required to always update the changes that occur, so that learning is able to prepare students to face the changes that occur. One of the important things that can be done by teachers is to develop HOTS-oriented learning so that students become accustomed to critical thinking so that they are able to develop their creativity. The purpose of this study is to determine the concept of higher order thinking skills, aspects of higher order thinking skills, HOTS-oriented learning characteristics. The results of this study are: Higher order thinking skills are thinking skills that are not just remembering, restating, and also referring without processing, but thinking skills to examine information critically, creatively, and able to solve problems, Skilloriented learning higher order thinking is learning that involves 3 (three) aspects of higher order thinking skills, namely: transfer of knowledge, critical and creative thinking, and problem solving. The characteristics of HOTS-oriented learning must make students active in thinking.
\end{abstract}

Keywords: HOTS, learning characteristics

\begin{abstract}
Abstrak
Guru senantiasa dituntut untuk selalu update terhadap perubahan yang terjadi, sehingga pembelajaran mampu menyiapkan siswa dalam menghadapi perubahan yang terjadi. Salah satu hal penting yang dapat dilakukan oleh para guru adalah mengembangkan pembelajaran yang berorientasi pada HOTS agar siswa menjadi terbiasa untuk berpikir kritis sehingga mampu mengembangkan kreatifitasnya. Tujuan penelitian ini yaitu untuk mengetahui konsep keterampilan berpikir tingkat tinggi, Aspek keterampilan berpikir tingkat tinggi, karakteristik pembelajaran yang berorientasi HOTS. Hasil Penelitian ini adalah : Keterampilan berpikir tingkat tinggi adalah kemampuan berpikir yang bukan hanya sekedar mengingat, menyatakan kembali, dan juga merujuk tanpa melakukan pengolahan, akan tetapi kemampuan berpikir untuk menelaah informasi secara kritis, kreatif, dan mampu memecahkan masalah, Pembelajaran yang berorientasi pada keterampilan berpikir tingkat tinggi adalah pembelajaran yang melibatkan 3 (tiga) aspek keterampilan berpikir tingkat tinggi yaitu: transfer of knowledge, critical and creative thinking, dan problem solving. Karakteristik pembelajaran berorientasi HOTS harus membuat peserta didik aktif dalam berpikir.
\end{abstract}

Kata kunci: HOTS, karakteristik pembelajaran

Social, Humanities, and Education Studies (SHEs): Conference Series p-ISSN 2620-9284 https://jurnal.uns.ac.id/shes 


\section{PENDAHULUAN}

Pendidikan menurut UNESCO (Danim, 2010) meliputi empat pilar, yaitu belajar mengetahui (learning to know), belajar melakukan sesuatu (learning to do), belajar menjadi sesuatu (learning to be) dan belajar hidup bersama (learning to life together). Salah satu pilarnya yaitu learning to know menurut Danim (2010) merupakan belajar dengan mengembangkan dua sisi konsentrasi, yaitu kemampuan memori dan kemampuan berpikir. Pembelajaran abad 21 secara sederhana diartikan sebagai pembelajaran yang memberikan kecakapan abad 21 kepada peserta didik, yaitu 4C yang meliputi: (1) Communication (2) Collaboration, (3) Critical Thinking and problem solving, dan (4) Creative and Innovative. Kehidupan di abad ke-21 menuntut berbagai keterampilan yang harus dikuasai seseorang, sehingga diharapkan pendidikan dapat mempersiapkan siswa untuk menguasai berbagai keterampilan tersebut agar menjadi pribadi yang sukses dalam hidup. Keterampilan-keterampilan penting di abad ke-21 masih relevan dengan empat pilar kehidupan yang mencakup learning to know, learning to do, learning to be dan learning to live together. Empat prinsip tersebut masing-masing mengandung keterampilan khusus yang perlu diberdayakan dalam kegiatan belajar, seperti keterampilan berpikir kritis, pemecahan masalah, metakognisi, keterampilan berkomunikasi, berkolaborasi, inovasi dan kreasi, literasi informasi, dan berbagai keterampilan lainnya (Zubaidah, 2016).

Pembelajaran dan penilaian pembelajaran berbasis keterampilan berfikir tingkat tinggi (higher order thinking skill /HOTS) atau berpikir kritis direkomendasikan untuk di selengarakan dalam proses pendidikan yang bermutu. Implementasi pembelajaran dan penilaian berbasis HOTS ini diharapkan mampu meningkatkan mutu dan kompetensi lulusan dalam rangka menghadapi era persaingan bebas pada revolusi industri 4.0. Pembelajaran yang melibatkan berfikir tingkat tinggi (higher order thinking skill/ HOTS) diperlukan pada era revolusi industri 4.0 seperti sekarang ini. Ilmu pengetahuan dan teknologi yang terus berkembang berpengaruh terhadap perubahan yang terus berlangsug tanpa henti di segala bidang sebab perubahan terus berlangsung, manusia dituntut untuk dapat menyesuaikan diri melalui perubahan sikap mental, pengetahuan, dan keterampilan. Manusia dituntut untuk selalu terus belajar dalam rangka pengembangan potensi diri hingga dapat bertahan (memecahkan masalah dalam hidupnya) dan siap bersaing untuk meningkatkan kesejahteraan hidup (Helmawati, 2019).

Menurut Nugroho (2018) mendidik peserta didik dengan HOTS berarti menjadikan mereka mampu berpikir. Peserta didik dikatakan mampu berpikir jika dapat mengaplikasikan pengetahuan dan dapat mengembangkan keterampilan yang dimiliki dalam konteks situasi yang baru. HOTS sebagai berpikir kritis di definisikan sebagai keterampilan memberikan penilaian yang bijak dan mengkritisi sesuatu menggunakan alasan logis dan ilmiah. Tujuan pembelajaran, salah satunya adalah menjadikan peserta didik mampu mengungkapkan argumentasi, melakukan refleksi, dan membuat keputusan yang tepat.

Menurut Sani (2019) pembelajaran berbasis HOTS harus membuat semua peserta didik aktif dalam berfikir. Peran guru tidak begitu dominan dalam proses pembelajaran, namun lebih berperan sebagai fasilitator untuk memberi kemudahan bagi peserta didik dalam berpikir. Oleh sebab itu guru harus mempersiapkan tugastugas atau soal yang dapat membuat peserta didik berpikir kreatif, kritis, dan menyelesaikan masalah. Peserta didik diberi kesempatan untuk mengembangkan kemampuan berpikirnya sehingga menguasai kemampuan 3 berpikir tingkat tinggi. Oleh sebab itu, penerapan HOTS merupakan kebutuhan wajib yang harus diterapkan oleh seorang guru dalam proses pembelajaran di kelas, sehingga peserta didik dapat mengembangkan kemampuannya secara maksimal. 


\section{HASIL DAN PEMBAHASAN}

A. Konsep Berpikir Tingkat Tinggi

Berpikir merupakan suatu kegiatan mental yang terjadi ketika seseorang dihadapkan pada situasi atau suatu permasalahan yang harus diselesaikan. Kegiatan berpikir yang terjadi dapat berbeda-beda tingkatannya tergantung pada situasi atau kompleksitas masalah yang dihadapi. Suatu masalah mungkin dapat diselesaikan dengan tingkat berpikir yang lebih rendah seperti mengingat dan memahami. Masalah lain yang lebih kompleks memerlukan keterampilan berpikir yang lebih seperti menganalisis dan mengevaluasi.

Proses berpikir dan klasifikasinya yang paling dikenal dalam dunia pendidikan adalah Taksonomi Bloom. Dalam Taksonomi Bloom dirumuskan 6 level proses berpikir, yaitu mengingat (remembering), memahami (understanding), menerapkan (applying), menganalisis (analyzing), mengevaluasi (evaluating), dan mengkreasi (creating). Menurut Susan Bookhart (Pusat Penilaian Pendidikan : 2019) mengkategorikan tiga proses kognitif atas taksonomi Bloom, yaitu menganalisis, mengevaluasi, dan mengkreasi sebagai proses berpikir tingkat tinggi.

Keterampilan berpikir tingkat tinggi yang dalam bahasa umum dikenal sebagai Higher Order Thinking Skill (HOTS) dipicu oleh empat kondisi (Yoki Ariyana dkk :2018).

a. Sebuah situasi belajar tertentu yang memerlukan strategi pembelajaran yang spesifik

b. Kecerdasan yang tidak lagi dipandang sebagai kemampuan yang tidak dapat diubah, melainkan kesatuan pengetahuan yang dipengaruhi oleh berbagai faktor yang terdiri dari lingkungan belajar, strategi dan kesadaran dalam belajar.

c. Pemahaman pandangan yang telah bergeser dari unidimensi, linier, hirarki atau spiral menuju pemahaman pandangan ke multidimensi dan interaktif.

d. Keterampilan berpikir tingkat tinggi yang lebih spesifik seperti penalaran, kemampuan analisis, pemecahan masalah, dan keterampilan berpikir kritis dan kreatif.

Menurut Resnik (Yoki Ariyana dkk:2018) Keterampilan berpikir tingkat tinggi adalah proses berpikir kompleks dalam menguraikan materi, membuat kesimpulan, membangun representasi, menganalisis, dan membangun hubungan dengan melibatkan aktivitas mental yang paling dasar.

Menurut Ernawati (Aningsih:2018) Keterampilan berpikir tingkat tinggi atau higher order thinking skill (HOTS) adalah cara berpikir yang tidak hanya menghafalsecara verbalistik saja namun juga memaknai hakikat yang terkandung diantaranya, untuk mampu memaknai makna dibutuhkan cara berpikir yang integralistik dengan analisis, sintesis, mengasosiasi hingga menarik kesimpulan menuju penciptaan ide-ide kreatif dan produktif.

Berdasarkan beberapa pendapat tersebut dapat disimpulkan bahwa keterampilan berpikir tingkat tinggi atau Higher Order Thinking Skill (HOTS) adalah kemampuan berpikir yang bukan hanya sekedar mengingat, menyatakan kembali, dan juga merujuk tanpa melakukan pengolahan, akan tetapi kemampuan berpikir untuk menelaah informasi secara kritis, kreatif, dan mampu memecahkan masalah.

\section{B. Aspek Keterampilan Berpikir Tingkat Tinggi}

Pembelajaran yang berorientasi pada Keterampilan Berpikir Tingkat Tinggi adalah pembelajaran yang melibatkan 3 (tiga) aspek keterampilan berpikir tingkat tinggi yaitu: transfer of knowledge, critical and creative thinking, dan problem solving.

1. Keterampilan Berpikir Tingkat Tinggi Sebagai Transfer of Knowledge 
Keterampilan berpikir tingkat tinggi erat kaitannya dengan keterampilan berpikir sesuai dengan ranah kognitif, afektif, dan psikomotor yang menjadi satu kesatuan dalam proses belajar dan mengajar.

Ranah kognitif meliputi kemampuan dari peserta didik dalam mengulang atau menyatakan kembali konsep/prinsip yang telah dipelajari dalam proses pembelajaran yang telah didapatnya. Proses ini berkenaan dengan kemampuan dalam berpikir, kompetensi dalam mengembangkan pengetahuan, pengenalan, pemahaman, konseptualisasi, penentuan dan penalaran.

Kartwohl \& Bloom juga menjelaskan bahwa selain kognitif, terdapat ranah afektif yang berhubungan dengan sikap, nilai, perasaan, emosi serta derajat penerimaan atau penolakan suatu objek dalam kegiatan pembelajaran dan membagi ranah afektif menjadi 5 kategori, yaitu seperti pada tabel di bawah.

Keterampilan proses psikomotor merupakan keterampilan dalam melakukan pekerjaan dengan melibatkan anggota tubuh yang berkaitan dengan gerak fisik (motorik) yang terdiri dari gerakan refleks, keterampilan pada gerak dasar, perseptual, ketepatan, keterampilan kompleks, ekspresif dan interperatif.

2. Keterampilan Berpikir Tingkat Tinggi Sebagai Critical dan Creative Thinking

HOTS sebagai Critical and Creative Thinking, secara esensial sebagai sebuah proses aktif, dimana seseorang berpikir segala hal secara mendalam, mengajukan berbagai pertanyaan, menemukan informasi yang relevan dalam memecahkan permasalahan yang muncul, mengambil keputusan, menganalisis semua asumsi yang muncul dan melakukan investigasi atau penelitian berdasarkan data dan informasi yang telah didapat sehingga menghasilkan informasi atau simpulan yang diinginkan. HOTS sebagai proses berpikir kritis dalam konteks pembelajaran adalah membentuk peserta didik yang mampu untuk berpikir logis (masuk akal), reflektif, dan mengambil keputusan secara mandiri.

3. Keterampilan Berpikir Tingkat Tinggi Sebagai Problem Solving

HOTS sebagai Problem Solving, diperlukan dalam proses pembelajaran, karena pembelajaran yang dirancang dengan pendekatan pembelajaran berorientasi HOTS tidak dapat dipisahkan dari kombinasi keterampilan berpikir dan keterampilan kreativitas untuk pemecahan masalah. HOTS sebagai proses penyelesaian masalah adalah menjadikan peserta didik mampu menyelesaikan permasalahan riil dalam kehidupan nyata, yang umumnya bersifat unik sehingga prosedur penyelesaiannya juga bersifat khas dan tidak rutin

\section{Karakteristik Pembelajaran Berorientasi HOTS}

Pembelajaran berorientasi pada keterampilan berpikir tingkat tinggi atau HOTS, peran guru tidak banyak menerangkan, sebaliknya guru banyak melakukan stimulasi pertanyaan untuk mendorong memunculkanya pikiran-pikiran orsinil peserta didik, pertanyaan-pertanyaan tersebut mencakup:

1. Pertanyaan untuk memfokuskan perhatian atau kajian untuk diperdalam.

2. Pertanyaan untuk mendorong peserta didik berpikir menemukan alasan atau mengambil posisi pendapat.

3. Pertanyaan untuk mengklarifikasi suatu konsep dengan arah bisa merumuskan definisi yang jelas lewat memperbandingkan, menghubungkan dan mencari perbedaan atas konsep-konsep yang ada.

4. Pertanyaan untuk mendorong munculnya gagasan-gagasan yang kreatif dan alternative lewat imajinasi. 
5. Pertanyaan untuk mendorong peserta didik mencari data dan fakta pendukung serta bukti-bukti untuk mengambil keputusan atau posisi.

6. Pertanyaan untuk mendorong peserta didik mengembangkan pikiran lebih jauh dan lebih mendalam, dengan mencoba mengaplikasikan sesuatu informasi pada berbagai kasus dan kondisi yang berbeda-beda, sehingga memiliki lebih banyak argumentasi.

7. Pertanyaan untuk mengembangkan kemampuan mengaplikasikan aturan atau teori yang lebih umum pada kasus yang tengah dikaji.

Dalam pembelajaran berorientasi HOTS harus membuat peserta didik aktif dalam berpikir. Oleh sebab itu, guru harus mempersiapkan tugas-tugas atau soal yang dapat membuat peserta didik berpikir kreatif, kritis, dan dapat menyelesaikan masalah. Peserta didik diberikan kesempatan untuk dapat mengembangkan kemampuan berpikirnya sehingga mampu menguasai keterampilan berpikir tingkat tinggi.

Pembelajaran yang membuat peserta didik dapat memformasikan masalah merupakan pembelajaran berbasis HOTS. Hal ini perlu bagi siswa untuk dapat merumuskan suatu permasalahan dari kondisi yang diberikan. Namun tujuan ini dilakukan untuk menyelesaikan sebuah masalah agar memudahkan peserta didik dalam memahami masalah.

Hal tersebut merupakan ajaran untuk melatih kreativitas siswa dalam menyelesaikan suatu masalah. Jadi dapat disimpulkan bahwa aktivitas merupakan suatu proses untuk dapat berpikir kreatif yang didapat oleh kemampuan siswa untuk merumuskan masalah dan mencari solusinya sebagai sarana untuk menilai kreativitas dan mendorong siswa untuk mengembangkan kemampuan kreativitasnya.

\section{SIMPULAN}

Keterampilan berpikir tingkat tinggi atau Higher Order Thinking Skill (HOTS) adalah kemampuan berpikir yang bukan hanya sekedar mengingat, menyatakan kembali, dan juga merujuk tanpa melakukan pengolahan, akan tetapi kemampuan berpikir untuk menelaah informasi secara kritis, kreatif, dan mampu memecahkan masalah. Pembelajaran yang berorientasi pada Keterampilan Berpikir Tingkat Tinggi adalah pembelajaran yang melibatkan 3 (tiga) aspek keterampilan berpikir tingkat tinggi yaitu: transfer of knowledge, critical and creative thinking, dan problem solving. Dalam pembelajaran berorientasi HOTS harus membuat peserta didik aktif dalam berpikir. Oleh sebab itu, guru harus mempersiapkan tugas-tugas atau soal yang dapat membuat peserta didik berpikir kreatif, kritis, dan dapat menyelesaikan masalah. Peserta didik diberikan kesempatan untuk dapat mengembangkan kemampuan berpikirnya sehingga mampu menguasai keterampilan berpikir tingkat tinggi.

\section{DAFTAR PUSTAKA}

Aningsih, Anugrah. (2018). Kemampuan Berpikir Tingkat Tinggi pada Pendidikan Agama Islam Siswa Kelas X SMK Muhammadiyah 1 Purwokerto Ditinjau dari Prestasi Belajar. Skripsi Fakultas Agama Islam Universitas Muhamadiyah Purwokerto.

Ariyana, Yoki. dkk. (2018). Buku Pegangan Pembelajaran Berorientasi pada Keterampilan Berpikir Tingkat Tinggi. Jakarta : Direktorat Jenderal Guru dan Tenaga kependidikan dan Kebudayaan.

Danim, Sudarwan. (2010). Pengantar Kependidikan. Bandung : Alfabeta. 
Helmawati. (2019). Pembelajaran dan Penilaian Berbasis HOTS (Higher order thingking skill). Bandung : PT Remaja Rusdakarya.

Nugroho, R Arifin. (2018). HOTS Kemampuan Berpikir Tingkat Tinggi : Konsep, Pembelajaran, Penilaian, dan Soal-Soal. Jakarta : PT Gramedia.

Sani, Ridwan Abdullah. (2019). Pembelajaran Berbasis Hots (Higher Order Thinking Skill). Tangerang. PT Tira Smart.

Tim Pusat Penilaian Pendidikan. (2019). Panduan Penulisan Soal HOTS-Higher Order Thinking Skills. Jakarta : Pusat Penilaian Pendidikan.

Wena, I Made. (2020). Pembelajaran Berorientasi HOTS (High Order Thinking Skill) di Era Revolusi Industri 4.0 untuk Mewujudkan Generasi Indonesia Emas 2045. Prosiding Mahasaraswati Seminar Nasional Pendidikan Matematika 2020.

Zubaidah, Siti. (2016). Keterampilan Abad 21 : Keterampilan yang Diajarkan Melalui Pembelajaran. Jurnal Seminar Nasional Pendidikan, 2 (2), 1-17. 